\title{
L2/FL TEACHER EDUCATION: BRIDGING THE COMPLEXITIES OF TEACHING AND THE LEARNING OF TEACHING
}

\author{
Karen E. Johnson ${ }^{*}$ \\ The Pennsylvania State University \\ State College, PA, USA \\ Adriana de C. Kuerten Dellagnelo ${ }^{* *}$ \\ Universidade Federal de Santa Catarina \\ Florianópolis, SC, BR
}

Research on approaches to and the complexities of second and foreign language (L2/FL) teaching has dominated the field of L2/FL teacher education for much of its history. While such research has helped to inform L2/FL classroom practices, research on the learning of teaching has been less prevalent but critical to informing the content and processes of both pre-service and in-service $\mathrm{L} 2 / \mathrm{FL}$ teacher education programs (Freeman \& Johnson, 1998). Four decades of research on teacher cognition in general teacher education and to a lesser extent in L2/FL teacher education has come to characterize the learning of teaching as a process of appropriation of culturally valued patterns of the social situations within which teachers interact on a regular basis. Typically this involves appropriating normative ways of acting and interacting that reflect the values, assumptions, and attitudes that are embedded in the classrooms where teachers were once students, in the teacher education programs where they receive their professional credentialing, and in the schools where they eventually work. As a result, this life-long process of appropriation shapes the complex ways in which teachers come to think, believe, and know about themselves, their students, and the activities of teaching and learning (Borg, 2006; Cochran-Smith et.al, 2008; Freeman, 2002; Kubanyiova \& Feryok, in press).

Yet, this process of appropriation becomes problematic when the values, assumptions, and attitudes of different social situations collide. This is often the case when teacher education programs attempt to move prospective teachers beyond teaching the way they were taught toward more theoretically and pedagogically sound instructional practices that meet the educational outcomes of the instructional contexts in which they will eventually work. Likewise, newly minted teachers who enter the workforce often find that what they experienced in their teacher education programs is not the way things are done in the real world of classroom L2/FL teaching. A major challenge for teacher education programs, as the quintessential site for the professional development of L2/FL teachers, is to empower teachers with the knowledge, judgments, dispositions, experiences and practical skills to navigate the turbulent waters that exist across the different educational spheres where both teaching and the learning of teaching take place.

\footnotetext{
* Karen E. Johnson is Kirby Professor of Language Learning and Applied Linguistics in the Department of Applied Linguistics at The Pennsylvania State University. Her research interests include narrative inquiry as professional development, teacher learning in second language teacher education, and sociocultural research and perspectives on language teacher professional development.

${ }^{*}$ Adriana de C. Kuerten Dellagnelo is Associate Professor at Universidade Federal de Santa Catarina, where she teaches both at the Graduate Program of (Applied) Linguistic Studies and at the Undergraduate Program of English. Her main research interest is the field of Foreign Language Teacher Education, particularly from a sociocultural perspective. She started developing research in this area after an experience as a visiting scholar at Penn State University (State College, PA - USA) in 2010-2011.
} 
This thematic issue attempts to bridge the complexities of teaching and the learning of teaching by exploring one such educational sphere - the practices of L2/FL teacher education. By practices, we mean the professional development activities that teachers and teacher educators engage in as an integral part of their pre-service or in-service L2 teacher education programs (Johnson, in press). Building on Johnson \& Golombek's (forthcoming) work, we concur that it is inside the practices of L2 teacher education where teachers can, and should be, intentionally supported as they come to terms with the complexities of teaching while simultaneously engaging in the learning of teaching. Likewise, we agree that it is within the practices of $\mathrm{L} 2$ teacher education where teacher educators can best see, support, and enhance the professional development of L2 teachers. Thus, we believe it is counter-productive to look at teaching as somehow separate from the learning of teaching as both are essential for the development of L2/FL teacher/teaching expertise, and are, in fact, dialectically related.

While some contributors to this thematic issue focus on the learning of teaching while teachers and teacher educators are engaging in recognized L2/FL teacher education practices, others focus specifically on the role of the teacher educator in supporting and enhancing the learning of teaching, before, during, and after actual teaching. And while the focus of the contributors' analytic gaze may differ, they share a common conceptualization of the learning of teaching as originating in and shaped by the specific social situations in which teachers engage. Several contributors ground their research in a Vygotskian sociocultural theoretical perspective on teacher learning (Johnson, 2009), looking specifically at the social activities that teachers and teacher educators engage in to see how the expert mediation that emerges during these activities reappears as mental activities in teacher thinking and pedagogical activity. Others draw on theories of situated cognition (Lave \& Wenger, 1991; Rogoff, 2003), examining and, in some cases, challenging the normative ways of reasoning and dominant instructional practices that exist in the specific communities of practice in which L2/FL teachers teach. Some contributors find that a productive byproduct of engagement in the practices of L2/FL teacher education is the development of reenvisioned teacher identities, explicating the dynamic and emergent relationship among and between L2/FL dominant discourses, teacher identity and classroom practices. Other contributors focus their lens on the broader institutional and/or policy macro-structures that in many educational settings are established to influence both how and what teachers are expected to accomplish in their L2/FL classrooms.

Besides drawing on ontologically different but compatible theories of teacher learning, the contributors to this thematic issue also draw on different methods of data collection and analyses. Some have created innovative pedagogical interventions where teacher educators explicitly and intentionally mediate in teacher learning for very specific professional development goals. Some have looked micro-analytically at talk-ininteraction to uncover the complexities of and to develop a heightened awareness for how real-time teaching gets enacted in language classrooms. Still others have set up tasks, assignments, and/or research projects in which teachers critically reflect on themselves as teachers, their pedagogical activities, and/or the institutional contexts in which they carry out their work, in essence, creating safe spaces in which teachers are encouraged to both explore and direct their own professional development.

Regardless of the theoretical perspectives and methodological tools that inform the research presented in this thematic issue, the element that unites this body of work is that teachers' sense making unfolds as teachers engage in reflection in and on the real-life activities of both teaching and the learning of teaching. The contributors to this thematic issue recognize the education of L2/ FL teachers as a process of co-constructing knowledge, dispositions, and practices through collaborative relationships in which teachers and teacher educators interact, learn, and develop professionally. And in the process of doing so, the practices they participate in, by design, are intended to create opportunities for teachers to critically reflect on and intellectually engage in and with theoretically and pedagogically sound concepts and instructional practices.

The first two studies in this issue focus specifically on practices (narrative inquiry, curriculum development 
project, and professional blogs) that helped create mediational spaces for critical self-reflection as teachers struggle with and seek to develop more productive L2/FL teacher identities. Golombek and Klager trace the development of a novice ESL teacher's identity as he worked to shift from being constructed as 'the grammar inquisitor' to creating 'synergy' in the teaching of L2 grammar. Conducting a narrative inquiry and materializing a curriculum development project created mediational spaces in which this teacher could 'play' with these images as he sought to recreate a new, more satisfying identity-in-activity (Cross, 2006). Key to his emerging identity-in-activity was the fact that he was teaching an actual ESL grammar course while conducting the narrative inquiry and simultaneously instantiating a genre-based curricular approach to teach grammar. Linking novice teachers experiences of teaching activity across time and space, and mediating them through teacher education practices such as narrative inquiry and curriculum development, create the potential to initiate rich experiences from which novice teachers can imagine, while developing the varied kinds of expertise needed for teaching, and shape their identities-in-activity.

Anjos-Santos and Cristovão analyze professional blogs produced by two pre-service EFL teachers as they reflected on and questioned the theories that underlie the pedagogical activities they were experiencing in their teacher education program. While externalizing their thoughts, these teachers expressed conflicts generated by the multiplicity of voices that echoed throughout their blog posts, at times finding convergence with the theories they were being exposed to yet at other times showing divergence. The professional blogs created safe spaces for critical reflection on moments of self-concern and identity (re)construction as well as moments of the (re)construction of their emerging professional knowledge about L2/FL teaching and learning. The findings point to the potential of professional blogs in challenging pre-service teachers' crystalized representations of language teaching and learning while simultaneously functioning as an instrument of formative mediation that can be utilized by teacher educators to support the development of L2/ FL teacher/teaching expertise.

While the persistent theory/practice dichotomy remains a challenge for all L2/FL teacher education programs, the next two studies in this issue focus on the dialectics between theory and practice through reflective work within a community of practice that, together, attempts to account for situated pedagogical practices. Both of these studies situate their research questions within the broader institutional and/or policy macro-structures that are present in the settings in which L2/FL teachers learn and teach. In Sarmento and Kirsch's article, they claim the English without Borders program - an internationalization public policy in Brazil - to be an effective site for L2/FL teacher professional development. In this program, held in every federal university in Brazil, graduate and undergraduate students of Applied Linguistics/Letters Programs teach English courses with the aim of granting Brazilian university students greater access to international academic mobility in countries where English is the official or dominant language of instruction. Although the English without Borders program was not originally intended to target teacher education, the professional development of the teachers who work in the program has become an important component of the program's success. Data collected from 16 teachers from the program at the Federal University of Rio Grande do Sul traces the formation and transformation of these teachers' professional identities while they engaged in the program, particularly through their engagement in weekly pedagogical meetings, (individual and group) lesson planning, actual teaching, and writing reports. Among these practices, the pedagogical meetings where found to be the most beneficial for teachers as they created opportunities for collective reflections about teachers' situated classroom practices with mediation from peers and more experienced others in this case, the program coordinators - and through theoretical and conceptual discussions that related to their attempts to (re)conceptualize their teaching.

Along the same vein, Gimenez, Stein, and Canazart examined the impact of Brazilian public policy, specifically PDE-Paraná, whose aim is to (re) 
qualify teachers who work in basic education along side their peers at university, thus align pedagogically sound approaches to English language instruction in both schools and universities. During the first year of the program, teachers are given a leave of absence so that they can participate full-time in activities offered by the partner higher education institution and/or professor. During that year they engage in course work as well as develop an individualized pedagogical project that meets the instructional needs that are endemic in their particular classroom setting. During the second year, now on partial leave, the teachers return to their classrooms where they are expected to implement the pedagogical project and disseminate and discuss the results of their work through the on-line Moodle platform with their peers. During the last stage of the program, teachers write an academic article presenting the results of their pedagogical projects and post it on a governmental platform for wide-spread professional distribution. A case study of one teacher's experiences in the program suggests this joint endeavor was a productive context for professional development that led to the (re)signification of her professional identity, the (re)creation of meanings to particular pedagogical practices, and the development of a higher level of self-assurance and autonomy. The researchers acknowledge, however, that this teacher's professional growth was largely the result of being granted a leave of absence without which the positive outcomes of such long-term school-university partnerships is unlikely to be sustained.

Productively focusing teachers' attention on their own talk-in-interaction and how (and why) they make particular pedagogical decisions while teaching is the analytic focus of the next three articles in this issue. Each study's research design creates safe meditational spaces for teachers and teacher educators to reflect on and engage in dialogic interactions about teachers' pedagogical reasoning and teaching activity. Fagan focuses on the challenge of effectively handling learner inquiries and exposes the intricate nature of the interactional work that goes on 'in the moment' of L2 teaching. Using the conventions of conversation analysis (CA), Fagan used transcripts to make visible an experienced ESL teacher's interactional responses to both problematic and unproblematic learner inquiries. Additionally, through ethnographic work (stimulated recalls \& interviews) the teacher was able to (re)construct a more fully articulated understanding of the rationale behind her interactional responses. Overall, Fagan's research provides evidence that this teacher was able to develop a more nuanced, more conscious awareness of her own interactional responses to learner inquiries. And this makes a compelling case for professional development interventions that pay attention to the intricacies of the interactional work (made visible by CA) that goes on in the activity of actual teaching. Moreover, since effectively handling learner inquiries is a challenge for both in-service and preservice teachers, being consciously aware of what these interactions look like as they are unfolding and being able to articulate a rationale for their use is a productive professional development exercise for all teachers.

Vásquez and Harvey analyze a mentor teacher's discourse during post-observation conferences with two novice ESL teachers. Setting up a clear rationale for the educational value of the Vygotskian (1935/1994) notions of everyday and scientific concepts and expert mediation through dialogue in the development of teaching expertise, their findings illustrate how the mentor teacher's discourse modeled conceptual thinking as she talked with these teachers about their teaching. The various ways in which the mentor modeled conceptual thinking (ideation, analytic ideation, terminizing, generalizing, principles) are placed on a horizontal continuum from the "contextualized nature of lived experience" to the "decontextualized nature of generalizations and principles." Additionally, the authors emphasize the dynamic, emergent, and contingent nature of the mentor's discourse; in other words, the quality and character of her discourse was always in relation to what was being talked about, who these teachers are, where they are teaching, and how they are responding/reacting to the mentor's discourse. An important implication of their research is "awareness of how conceptual thinking is represented in dialogues about teaching can help teacher educators to be more aware of their own language and to be more purposeful 
in their attempts to promote conceptual thinking in the teachers with whom they work."

Also working from a Vygotskian sociocultural theoretical perspective, Worden traces how an ESL teacher's understanding of a particular academic writing genre, the analytic essay, developed through her first semester of teaching a post-secondary second language writing class. Building on the theoretical construct of pedagogical content knowledge (Shulman, 1987), or the specialized content knowledge that teachers use to make the content they are teaching accessible, and useable for students, Worden traces this teacher's developing knowledge of the analytic essay while she engages in the activities of actually teaching it. Her findings indicate that the development of specialized content knowledge for teaching is neither fixed nor stable, but instead emergent, dynamic, and most importantly, mediated by the teacher's interactions with her students as well as through engagement in guided reflection about her teaching with the researcher. Worden's findings empirically document the dialectal relationship between the learning of teaching and actual teaching, illustrating in real-time what and how teachers learn as they engaged in the activities of teaching as well as how what they learn gets instantiated in how they teach. Additionally, Worden's research, like Fagan's and Vásquez and Harvey's, speaks directly to the design and enactment of teacher education practices in which teachers' own classrooms function as legitimate sites for productive teacher professional development.

Finally, Augusto-Navarro describes her own practices as a teacher educator who concurrently prepares students for learning English while simultaneously learning how to teach it. In so doing, she leads students to understand that teaching presupposes informed choices that account for context - target group, setting, content, resources and purposes of teaching. Accounting for this, she requires students to design either individually or in pairs - curricular materials for an imagined target audience, thus providing students with a theoretical foundation for the development of context-specific teaching materials. As they collectively and collaboratively discussed each others' curricular projects, they were found to revisit pre-existing beliefs, question their pedagogical choices, and justify their curricular decisions according to their particular subject matter content, instructional context, and teaching purposes. Based on students' blog posting, reports about the project, and voluntary written testimonies, teachers acknowledged that their curricular development experiences prepared them "to think of rationales for their pedagogical choices." Overall, Augusto-Navarro calls for the value of designing teaching materials in L2/ FL teacher education programs, suggesting that such socially situated tasks contribute to productive L2/FL teacher professional development.

Fundamental to each of the practices highlighted in this thematic issue are opportunities for teachers to externalize their thinking, to engage with the dialectics of theory and practice, to receive expert mediation from teacher educators, and to experience professional development practices that foster the emergence of new and/or reframed conceptualizations of being and becoming L2/FL teachers. In both teaching and the learning of teaching it is essential that L2/FL teachers are able to make theoretically and pedagogically sound judgments about the instructional issues to be worked on and to identify the resources that are necessary to support quality L2/FL student learning. A major contribution of this thematic issue is empirical research that documents what teacher education practices look and feel like as they are unfolding and the consequences of these practices on the ways in which L2/FL teachers begin to think about and attempt to enact their instructional practices. An equally important contribution of this thematic issue is empirical research that documents teacher learning as teachers engage in and reflect on the day-to-day activities that constitute L2/FL teaching and learning. Thus, these two foci of research seek to bridge the complexities of teaching and the learning of teaching in ways that reveal teacher education practices that productively support the development of L2/FL teacher/teaching expertise. 


\section{References:}

Borg, S. (2006). Teacher cognition and language education: Research and practice: London: Continuum.

Cochran-Smith, M., Feiman-Nemser, S., \& McIntyer, D.J. (Eds.) (2008). Handbook of research on teacher education: Enduring questions in changing contexts. New York: Routledge.

Cross, R. (2006). Identity and language teacher education: The potential for sociocultural perspectives in researching language teacher identity. In Teaching, and Education at the Australian Association for Research in Education Annual Conference: Engaging Pedagogies (pp. 27-30).

Freeman, D. (2002). The hidden side of the work: Teacher knowledge and learning to teach. Language Teaching, 35, 1-13.

Freeman, D., \& Johnson, K. E. (1998). Reconceptualizing the knowledge-base of language teacher education. TESOL Quarterly, 32, 397-417.

Johnson, K.E. (2009). Second language teacher education: A sociocultural perspective. New York: Routledge.

Johnson, K.E. Reclaiming the relevance of L2 teacher education. The Modern Language Journal. 99 (3).

Johnson, K.E. \& Golombek, P.R. (Eds.) (2011). Research on second language teacher education: A sociocultural perspective on professional development. NY: Routledge.

Johnson, K.E. \& Golombek, P.R. (forthcoming). Exploring the practices of L2 teacher education: Responsive mediation in learning to teach. NY: Routledge.

Kubanyiova, M. \& Feryok, A. Language teacher cognition in Applied Linguistics research: Revisiting the territory, redrawing the boundaries, reclaiming the relevance. The Modern Language Journal, 99 (3).

Lave, J. \& Wanger, E. (1991). Situated learning: Legitimate peripheral participation. New York: Cambridge University Press.

Rogoff, B. (2003). The cultural nature of human development. Oxford: Oxford University Press.

Shulman, L. S. (1987). Knowledge and teaching: Foundations of the new reform. Harvard Educational Review, 57 (1), 1-22.

Vygotsky, L.S. (1935/1994). The development of academic concepts in school aged children. In R. van de Veer \& J. Valsiner, (Eds.) (1994). The Vygotsky reader (pp. 355370) Oxford: Blackwell. 